Article

\title{
Gender Inequality and Symbolic Violence in Women's Access to Family Land in the Southern Highlands of Tanzania
}

\author{
Justin Lusasi ${ }^{1, *(\mathbb{D})}$ and Dismas Mwaseba ${ }^{2}$ (D) \\ 1 Department of Policy Planning and Management, College of Social Sciences and Humanities, \\ Sokoine University of Agriculture, Morogoro Box 3035, Tanzania \\ 2 Department of Agricultural Extension and Community Development, College of Agriculture, \\ Sokoine University of Agriculture, Morogoro Box 3002, Tanzania; dismasmwaseba@gmail.com \\ * Correspondence: julusasi@gmail.com
}

Received: 14 October 2020; Accepted: 5 November 2020; Published: 22 November 2020

\begin{abstract}
We set out to unveil gender inequality with respect to women's access to family land following the surge in tree-planting in selected villages in the Southern Highlands of Tanzania. Specifically, the study describes land-transaction procedures at the household level and shows how the lack of women's involvement in such land transactions affect their access to and control over family lands. Gender inequality is portrayed in a variety of social and economic activities, with women being deprived of access to, control over, and ownership of land. Although the current land laws address gender inequalities pertaining to women's access to, ownership of, and control over land, the impact of such reforms has been minimal. Drawing on Bourdieu's concept of symbolic violence, we reveal how women suffer symbolic violence through traditional practices of land management and administration. Societies in the studied villages are strongly patriarchal, with men being dominant and women subordinate. In such a patriarchal system, women's empowerment is urgent. Women require knowledge and awareness of the laws and regulations that affirm their rights not only to family lands, but also to participation in decision-making processes regarding family assets. We recommend non-oppressive approaches to natural-resource management. As such, we call for existing authorities at the village and district levels, Non Governmental Organisations (NGOs) and legal bodies to promote gender equality in land-management practices. We also advocate dialectical communication between women and men in order to reveal and heal practices of symbolic violence, and enhance gender equality in respect of access to land and its control and ownership in villages in the Southern Highlands of Tanzania. Effective implementation of existing land laws and regulations that address gender inequality and associated violence is unavoidable.
\end{abstract}

Keywords: gender; inequality; access; land; symbolic violence; Southern Highlands; Tanzania

\section{Introduction}

Gender mainstreaming constitutes a fulcrum for development planning and an entry point to the successful management of natural resources in developing countries [1]. This has been advocated by the United Nations General Assembly through its fifth Sustainable Development Goal (SDG), which targets achieving gender equality and empowering all women and girls by 2030 [2]. Gender equality, achievement of which still requires global efforts from small units in rural areas to highly developed communities, is a pillar for attaining a peaceful, prosperous and sustainable world.

Notwithstanding geographical disparities involved, most societies exhibit gender inequalities in access to and control over and the management of land and landed resources, including forests, 
with women being the victims in this situation [3,4]. In most areas of rural Tanzania, land ownership is guided by traditions, customs, and taboos that legitimize some groups of people as landowners, while excluding others [5]. Although some societies use criteria, such as age, marital status, and wealth to identify those who are entitled to access land [6], others use gender differences and traditional taboos as criteria determining access to, use of, and control over this natural resource [1]. In the book Gender, Environment, and Development, Heleen van den Hombergh describes the importance of gender concepts in environmental debates. Although Hombergh admits that men and women use natural resources differently and at different rates [7], other scholars argue in addition that men and women do not have equal rights to resources, nor can they draw equal benefits from them [8].

Gurung and colleagues, studying a society of the Hindu Kush in the Himalayas, described women as having access to and being involved with low-value non-timber products, including collecting and fetching firewood, fodder, and medicinal herbs, which serves immediate social demands, while men undertake the more laborious and heavier tasks of felling trees and cutting branches [8]. Similar observations were made by Follo and colleagues [4] in their analysis of gender in relation to forest ownership in Europe. They described private forests as forming a male system that is experiencing some changing dynamics, as women emerge as new forest owners. As Aelst and Holvoet observed [9], unlike men, women are restricted from owning important resources, which forms an obstacle to the development of sustainable rural livelihoods. Despite such marginalization, through gender, women's triple roles of reproduction, production, and community services, can be seen as having more interaction with nature, than is the case with men, giving them broader knowledge of land productivity, possible natural tree species, and the deleterious impacts of the mismanagement of natural resources, including land [10]. Moreover, women endure violations of conscious choices in their day-to-day practices because the violations are misrecognized and, hence, normalized. This is because of symbolic violence: "in order to be socially recognized, symbolic violence must get itself misrecognized" [11].

For rural development to be realized, synergistic efforts involving both men and women to use the existing natural resources of land, water, biodiversity, and the like, effectively are unavoidable. Unfortunately, women do not enjoy full involvement in the management of natural resources because of traditions and taboos that oppose this [1]. When it comes to positions of power, most African women are subordinate to men, which, in the long run, influences social relations, and, hence, the management of natural resources, community development, and family livelihoods [12].

Several studies $[3,6,13,14]$ have addressed women's access to land in Tanzania and Africa. Building on these studies, and drawing in particular on Pierre Bourdieu's symbolic violence, an insidious and invisible form of male domination over women, this study analyses the gendered access, control and management of family land in the Southern Highlands of Tanzania following a recent surge in tree-planting that requires the acquisition of more land. More specifically, the study describes land transaction processes at the household level and the manner in which the lack of women's involvement in such transactions affects their access to and control over family land. The paper is organized as follows. The background section assesses the availability of village land for tree-planting and the rush for timber. This is followed by a presentation of the conceptual framework, followed by a description of the methods of data collection and analysis. The findings and a discussion are presented next, followed by the conclusion at the end of the paper.

\section{Background}

The surge in tree-planting activities in the Southern Highlands of Tanzania, just mentioned, is largely a result of the dwindling supply of timber from the Sao Hill state plantation in the 2000s [15], which has motivated both private companies and individuals to fill the shortage. Early sales from private woodlots generated enormous earnings, making the timber trade a lucrative business. This has in turn stimulated the participation of different categories of domestic investor, ranging from village residents to urban dwellers, to rush to the villages and acquire village land on which to plant trees [16]. The multitude of tree-growers that have now surfaced has fuelled formal and informal 
transactions of village lands between indigenous smallholders and tree-growers, practices that have transformed potential cropland into woodlots $[17,18]$. While urban-based investors see tree-planting as a lucrative business, smallholders have found that their land has suddenly become a profitable commodity, leading them to become involved in land transactions to make money. However, as these transactions are conducted and/or supervised by men, they benefit them more than they benefit women. Although socially recognized, the complementary domination of men over women that can be observed amounts to symbolic violence [11].

Tanzania's land reforms, such as the Land Act and the Village Land Act of 1999, have the aim of eradicating gender inequalities in land ownership. However, these reforms have yet to be fully realized [6]. Although they have decentralized the land administration system to lower-level state organs such as village councils (VCs) to ensure, among other things, equality in land transfers and ownership between men and women, these reforms have still not reached rural communities. Where they have done so, significant barriers have been encountered that limit their implementation. Since land is an indicator of economic well-being, the traditions and taboos that restrict women from managing land cement their marginalization and discrimination in the management of natural resources.

At the beginning of the African land rush, Sam Moyo and Yeros asserted that the scramble for agricultural land and reforms to land tenure being promoted by neoliberal policies have had significant negative impacts on livelihoods and welfare, especially among women, who in most cases take the lead in the social reproduction of households [19]. Similarly, a scholarly work on land reforms in Africa by Rasmus Pedersen showed this scramble for land going hand in hand with the individualization of land parcels [6], a practice that further strengthens men's as opposed to women's control over land. The on-going tree-planting activities in the Southern Highlands of Tanzania have economic, religious, cultural, social, and environmental impacts regarding the loss of medicinal herbs, natural food stuffs, fuelwood, fodder, grazing lands and ritual sites, as well as the degradation of catchment areas, with the eventual impacts being skewed towards women $[8,20]$.

Traditional practice in some African societies dictates that women cannot inherit land or landed properties but must access land through their male relatives, such as their fathers and husbands $[1,3,6]$. Although they form the largest proportion of adults in Tanzania, and although agriculture is their main form of employment, women do not have rights to immovable resources, such as land [5]. Thus, their marginalization is traditionally created and maintained by societies that recognize men as the dominant group and women as subordinate [21].

The assumption that access to land is becoming less gendered, that is, that it now relies less on a woman's relations with her male relatives, is still subject to qualification [6]. In most of Sub-Saharan Africa, access to land is a masculine right, which still causes women to access land through marriage or other male relatives. Although this situation affects women differently, their effects are no less profound [22]. In the wave of land reforms in different African states in the 1990s, Tanzania enacted two pieces of legislation: the Land Act and the Village Land Act, both of 1999. While recognizing existing customary rights, these laws decentralized land administration system to village councils, and prohibited discriminatory practices preventing access to land by women [23]. Specifically, Section 3 (2) of the Village Land Act stipulates: "the right of every adult woman to acquire, hold, use, deal with and transmit land by or obtain land through the operations of a will, shall be to the same extent and subject to the same restrictions as the right of every adult man." To safeguard women's rights to land, the acts provide for women's participation in organs of land administration. Thus, the Village Council must include more than two women, the Village Adjudication Committee more than three [24]. The law insists that any custom that denies land rights to women, children or individuals with disabilities shall be void and inoperative [23].

Despite such interventions, land access remains skewed more to men than to women, although practice has improved somewhat [6]. Even though more men register for land ownership than do women, land rights to both genders are firmly recognized. In fact the current reforms, though far from being fully implemented, are fostering the individualization of land parcels. Coupled with the 
increased pace of tree planting, which increases the pressure on land, land transactions have disrupted customary practices that ensured access to land for divorced women and widows. Thus in many traditional societies, women still suffer from discrimination [14].

\section{Conceptual and Methodological Approaches}

\subsection{Conceptual Framework}

The current study is inspired by rampant transactions of village lands in the Southern Highlands of Tanzania. Specifically, this study was conducted in Mufindi, Makete, Wanging'ombe, Kilolo, and Njombe Districts (Figure 1), where land transactions in support of tree-planting have become very frequent. Land is being transformed into a commodity, one that is readily available for sale to domestic investors, who use it to grow exotic trees of pine and eucalyptus. As observed earlier, most land-sellers are men, who undertake these transactions even when women (wives or mothers) oppose it, a further demonstration of the power imbalance between men and women, with women ranking low in both power and status [21,22]. The rush for timber and, hence, for tree-planting, is not so widely observed in other parts of Tanzania as in the Southern Highlands, especially in the Njombe and Iringa regions, where planting timber trees was a state affair, until supplies of timber from state estates, such as Sao Hill, dwindled to their lowest levels [15].

There is a long history of struggles against female discrimination, as is reflected in the use of different terms [25]. Several concepts, such as psychoanalytical feminism, liberal feminism, radical feminism, radical cultural feminism, and liberal political theory, advocate the equality of all, in spite of differences of gender [26,27]. However, societies in different parts of the world have embraced practices that perpetuate the power imbalance between men and women [11]. Pierre Bourdieu describes the dominant practices that deprive subordinates of agency and voice as symbolic violence, a non-physical form of violence that is manifested in the power asymmetry between social groups, which is 'exerted for the most part through the purely symbolic channels of communication and cognition, recognition or even feeling' [27]. Symbolic violence exists in either recognized or misrecognized forms, may or may not be challenged, and may be changed or unchanged [28]. Thus, misrecognition is the highest level of symbolic violence, occurring in most natural settings and social practices, and demonstrating the highest level of a lack of consciousness regarding such practices [29]. James David unpacked the meaning of misrecognition in Bourdieu's view, seeing it as a result of day-to-day practices that give meanings, with the result that things, situations, and processes are ultimately not recognised for what they really are because of previous cognition within the habitus of those confronting it [30]. Since a thing, situation, or act is attributed to another realm of meaning, interests, inequalities, domination, and other effects continue as natural and covered. Nancy Fraser called being misrecognised as being "denied the status of full partner in social interaction and prevented from participating as a peer in social life ...." [31]. Misrecognition engenders subjects "unworthy of respect or esteem". When accepted as normal social practices, actions of disrespect and a lack of esteem interfere with equal participation among social groups, inequalities that amount to symbolic violence. Thus, misrecognition is a form of knowledge derived from social practices that act as capital to a person, granting power and prestige to the possessor. For instance, the androcentric practices of natural resource management among global societies are taken for granted (doxic) practical values that receive little questioning from either men as dominant or women as dominated [28]. Similarly, the traditional arrangements of most rural societies in the global south grant powers to men as the owners of immovable natural resources and, hence, as owners, decision-makers, and the rightful owners of land [29,32]. Concrete and symbolic violence are both active mechanisms of social life tied to the order of domination and destruction [33]. Though not visible, practices of symbolic violence are equally destructive, as they create a dichotomy of freedom and constraint through misrecognition, condescension, consent and the complicity of one group in subordinating another [11,27,34]. It is through misrecognition that practices of symbolic violence are perceived differently from what they really are, hence being accepted as a natural way of 
life in the society concerned [35]. In practice, women's silence regarding men's dominant practices not only generates unequal power relations, it also makes acceptance more difficult and, hence, leads to the reproduction of subordinates' own subjection [36]. Societies have accepted and internalized such social control and complementary domination over women on the part of both men and women. Symbolic violence exceeds the covert inequality and domination of women perpetrated by men, as it extends to commodity market systems where economic conditions exclude, marginalize, disenfranchise and promote gender inequalities [33]. Thus, disparities in the parental care given to daughters versus sons, restrictions in the form of do's and don'ts, and submission in marriage, groom symbolic violence, which is nonetheless perceived by societies as natural, given and unchangeable [11].

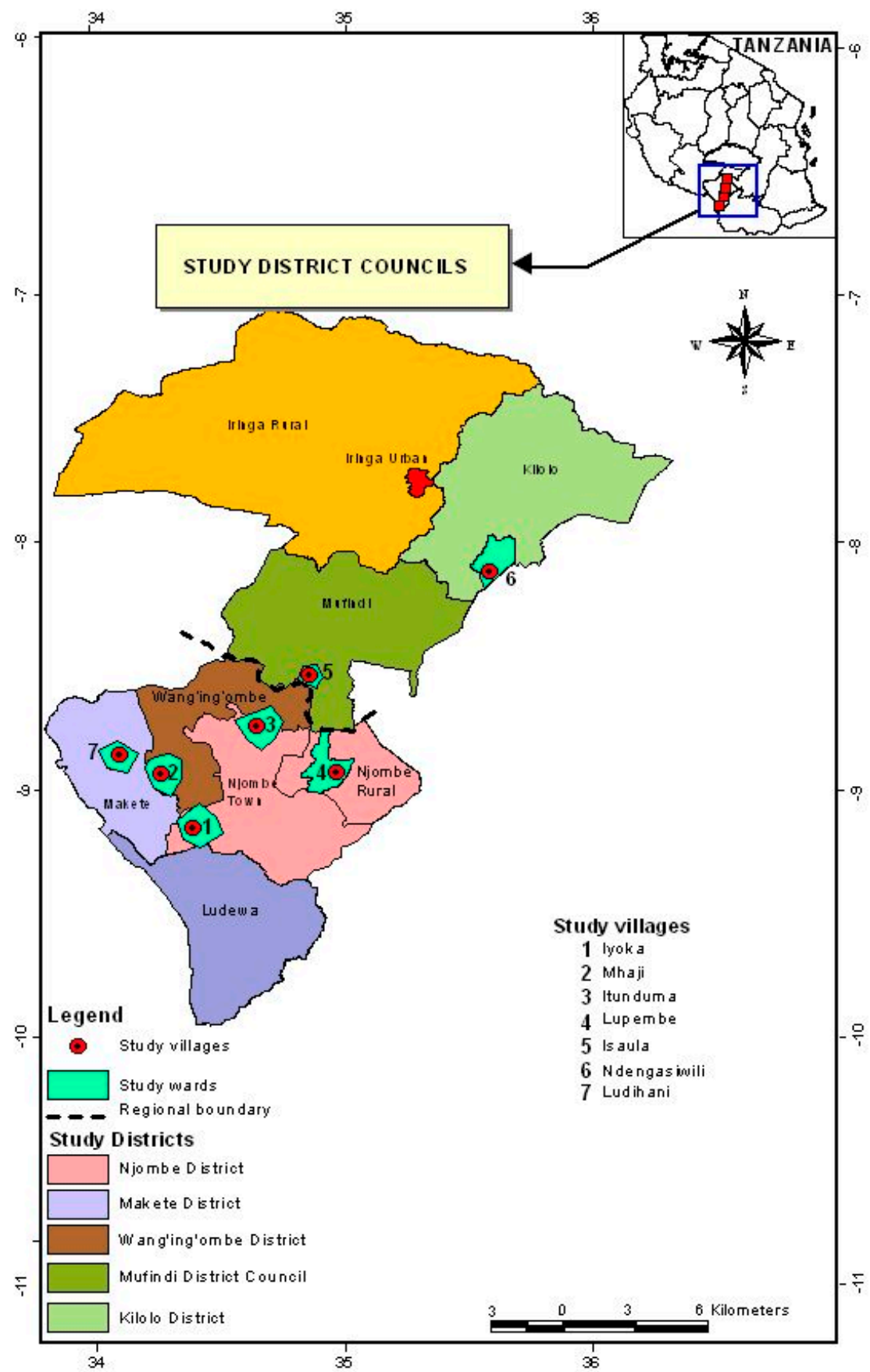

Figure 1. Map of Tanzania showing the study districts and their respective villages. (Source: Timber Rush Project). 
Violence in its different physical and symbolic forms exists in different areas of human activity, from laws to gender relations and racial discrimination [33]. Durey identifies at least three areas where social practices manifest symbolic violence and hence misrecognition, thus, undermining women's potential, namely unequal pay between men and women for the same type and amount of work, restrictions on women having further education and professional careers, and full-time employed women bearing primary responsibilities in the household, including for children care [35]. Although collective voices demanding women's empowerment and approaches, such as Women in Development (WID) and Gender and Development (GAD), try to foster women's recognition and empowerment in different countries, they are far from being successful when measured globally. However, practices of symbolic violence can be challenged and sometimes changed once they are recognized [27]. Social competition is one strategy that had been adopted by courageous but dissatisfied members of subordinate groups when they call for change by challenging the dominant group. This has led to changes in the social identity, status, material disposal and symbolic inequalities of some of the reported cases $[3,6,21,29]$.

\subsection{Methods}

The study adopted a qualitative approach involving data collection through in-depth interviews and focus-group discussions with women specifically selected from households involved in land transactions. Before the interviews and focus-group discussions started, the respondents were informed about the aims of the study, and their consent to participate in it and to have their voices recorded was sought verbally. After agreeing to participate, they were assured that their identities would be kept anonymous and their responses confidential. In addition, they were told they had the right to withdraw from participation at any time if they felt it appropriate to do so. The collected data were transcribed verbatim and analysed by means of directed content analysis [37]. The study involved ten female respondents from seven villages (Figure 1) with the following distribution: Isaula (3), Mhaji (2), and one from Lupembe, Iyoka, Itunduma, Ndengisivili, and Ludihani villages. Since the study aimed at understanding the nature of land transactions and women's attitudes to them, each respondent was involved in a semi-structured interview that focused on issues concerning land transactions. More specifically, the interview inquired after their involvement in land transactions, their attitudes to them and the impacts of such transactions on their livelihoods. Although the sample for the study was small, limiting its generalizability to issues of symbolic violence in the Southern Highlands, it highlights and, thus, enables one to understand the women's experiences in relation to symbolic violence driven by land transactions in the study areas.

Moreover, the analyses in this study are situational in nature, with interviews being conducted with specific targets, namely women, with respect to their experiences regarding access to land as impacted by rampant land transactions for tree-planting. The caveat made by Follo [4], namely that when data are collected from a family or the head of a household as a unit of analysis, one obtains more from men than from women, proved applicable in this case. As a result, husbands and wives were interviewed separately, thus giving women adequate space to explain things in detail. Thus, husbands were interviewed about their motives for selling land, while women were interviewed regarding their involvement in land transactions. Thapar-Bjorkert and colleagues have described interviews as a source of knowledge that, though created by individual perspectives, makes social structures and collective processes through individual narratives that are never ordinarily direct become direct and be constructed discursively [11]. The interview tool consisted of a checklist of guiding questions on land ownership, transactions and violent practices associated with land and the acquisition of landed resources. More specifically, wives were interviewed on their involvement in land transactions and on the manner in which these have had some influence on their welfare. On average, it took about an hour to complete an interview with one respondent. Four focus group discussions (FGDs) with eight to nine women in a group were also conducted in Isaula, Mhaji, Itunduma and Ndengisivili villages. A convenient sampling method was employed in choosing the women for the 
FGDs. Women of different ages, status and education were recruited. It took about an hour and a half to complete an FGD. Generally, data-collection processes through interviews and FGDs were open, critical and included dialogical interactions [28]. During interviews with men, we sought their opinions on women's participation in land transactions. Most men insisted that women "know nothing" or that women cannot say anything important about these matters because they are not supposed to be involved. This is an example of the social practice of Othering and of the testimonial epistemic violence of silencing [36], where men tend to disparage the knowledge and intellect of women, thus disabling them from speaking. To overcome the challenges involved here, we avoided having men in FGDs. This promoted the epistemic agency of the women, who eventually felt comfortable and able to tell everything [36].

\section{Results and Discussion}

\subsection{Patriarchal Systems and Gender Inequality in Accessibilty to Land}

The phrase symbolic violence refers to a situation in which powerful actors continue to enjoy unchallenged privileges in accessing resources and power through which they dominate social interactions [11]. Different forms of domination and violence against women, both physical (e.g., beating) and psychological, also called symbolic violence, are widely reported from across the globe $[10,11,28,29,33,35]$, including from communities in the Southern Highlands of Tanzania. This study uncovered social practices that maintain the status of men as a dominant social group whose plans and decisions regarding resource use and misuse are seldom challenged by women. In fact, marriage, which brings individuals together as couples, is implicated in many social settings, including raising children and making a family and a household, but not in the management of economic assets such as land. In the study villages, the patriarchal system of human relations, which subjugates women in matters related to resource ownership, still prevails. When it comes to land and landed resources, men in all cohorts are symbolically entitled to ownership through inheritance or allocation by the elders of the clan or tribe, while women are disadvantaged. When asked the reasons for unequal land distribution practices, a woman at Mhaji Village stated men's views of land ownership among girls and women by saying:

"A girl is not given land because upon marriage she will go away and lose a family identity and perpetuate her husband's identity. Therefore, she will get land where she gets married. Boys will remain in the family, hence are given land to establish settlements and for crops to feed their families". (Interview at Mhaji village on 9 November, 2019).

Thus, although women are involved in the management of family lands, they are not entitled to own the resource, but only to use it for the purposes of improving the household's well-being. A similar account was given by women in an FGD in Isaula village, who complained with one voice against the traditional social practices that limit women and daughters from owning immovable resources such as land and trees, on the basis that, as women do not contribute to the development of the clan, they should not participate in its inheritance.

Although rural families sustain the doxa regarding domination and subordination ${ }^{1}$, some married women problematize these social practices by demanding equal treatment and consideration, and hence a share of the benefits from economic assets like land. In one of the interviews, an obviously aggrieved woman shared the bitter words she had received from her husband when she demanded a share of the gains from the land he had sold to tree planters,

"You want the share of money, but when we got married, did you come with the soil from your father?" (Interview at Isaula village, 17 April 2018).

\footnotetext{
1 A society's taken for granted, unquestioned truths (after Bourdieu).
} 
This response, apart from psychologically abusing the woman, negates her agency and voice by treating her as a nothing or nobody. This misrecognition of her potential position and her silence legitimizes the power of men over women, thus perpetuating symbolic violence, which is harder to recover from than physical violence $[11,35]$. Such attempts by women to challenge these long-standing dominant practices are in vain. A woman cannot make any further demands because no one will support her claim against her husband, thus making her demand unreasonable. This kind of male practice portrays male dominance in society as a natural phenomenon, hence legitimizing women's subordination [35] and treating them as unworthy of respect and esteem [36].

\subsection{Land Transactions for the Surge in Tree Planting Have Perpetuated the Disadvantaging of Women in Respect of Land Ownership}

According to the relevant literature, land is an asset that can raise women's economic well-being in the form of money or income earned from the lease or sale of land [3,32,38] and, thus, reduce their poverty [39]. Some daughters and women in the study villages have realized the opportunities presented by land and, therefore, claim their share of land from their fathers. Their efforts to show their agency and voices are nonetheless in vain because of the misogynistic behaviour of their fathers. It is striking that mothers are not asked to intervene in matters of control over resources because they too are victims of similar situations. An interview with a young married woman revealed that, after being refused by her husband because she is not a member of his clan, she and her young sister, who has married elsewhere, resorted to claiming ownership of land from their biological father. As could be expected, they were disappointed to hear their father denying them access to land because they were married. Instead, he told them that their husbands should handle all issues regarding land. After weighing up the negative statements made by her husband and father, the older sister blamed her father by saying:

"Why is my father treating me like this? I am his daughter like my brothers. I deserve a share of land, even if it's just a little plot." (Interview in Isaula on 17 April 2018).

Although cases of women's marginalization persist, some of them acknowledge that some changes have been made in society and that some families treat their children equally. Asked about her experience of land acquisition at Isaula village, one woman (61 years old) said:

"In the past, it was a system that land is given to boys only. Girls were told that they would get land from the families to which they get married. Even for crops, there was a strong monopoly that a woman had no rights to sell her farm produce, and this practice still exists in some families here. We are thankful to people from Participatory Ecological Land Use Management (PELUM) ${ }^{2}$ for helping a lot to change this." (Interview on 17 April 2018).

Women are subjected to social pressure that restricts them in realizing their potential, including the expression of their rights and interests. According to Idris, factors that limit women's economic potential include time poverty, ignorance, reproductive pressure, a lack of assets, a lack of financial services, a lack of male support and labour, and cultural norms [5]. Due to symbolic violence, which restricts women in furthering their education, rural women remain potentially less educated and are hence subjected to social pressure that deters them from claiming their rights and limits their awareness of what to do when they are denied their rights [40]. Although Tanzania's land laws [41] provide for access to land resources by marginalized groups, including women, the factors mentioned in this paper render the provisions unproductive.

2 PELUM is an acronym for Participatory Ecological Land Use Management. It is a USAID-funded NGO that established the Isaula Village Land Use Plan, and also surveyed land parcels for individuals. They thus sensitized married women being co-owners of land plots with their husbands and women to being the sole owners of land parcels. 
Some women accept the restrictions imposed by men simply in order to preserve harmony in the family, which contributes to their subjugation. In one case, a divorced woman started her life in the house she had built on land given her by her father. Since marrying another man, who moved into her house, she has complained of the domination she experiences in her own house. Although she is proud of having her own house, she still faces similar challenges in her marriage. She recognizes the domination she is experiencing, but her respect for her husband has led into her debt and dependence and exposed her to ingratitude [11]. When asked about her experience of her marriage, she had this to say:

"Sometimes he overreacts to some issues as if am staying at his house. He intervenes in some of my plans with trees that he found there after marrying me. I do not like that. (Interview at Mhaji, 9 November 2019).

When asked why she does not stand firm and insist on her plans, she said,

"A man needs a woman who is submissive, otherwise he will be stressed. So I just cool down and listen just to make him feel honoured."

Although she is not in agreement with her husband's practices, she decided to accept his mistreatment of her so as not to prolong the disagreements, thus accepting the man's wrong-doing but falling complicit [11] in her own subjugation. Thus, submission to symbolic violence turns women into the involuntary servants of the norm of male domination. However, this finding on woman's experience of gender relations contrasts with the findings reported by Panda and Agarwal, who considered land ownership to be a factor in reducing tolerance to violence, when they say, 'Women owning immovable properties-land and a house-are found to face a significantly lower risk of marital violence than property-less women' [29]. These properties are considered a security guarantee that can support a woman in escaping from a violent environment. Land and a house can provide a minimum of basic needs, shelter, food and clothing. Ownership of such properties provides freedom from social deprivation, poverty and poor economic opportunities, which, according to Amartya Sen, is by itself development [42]. This observation was substantiated by a woman with four children who was divorced after staying in her marriage for nine years. During her first marriage, she did not own a piece of land or a house and instead had to depend on her husband, who mistreated her in several ways, including insults, slaps, beating, threats of abandonment and eventually a divorce. Lack of assets such as land and a house compelled her to seek refuge with a man who had showed interest in her, and she hence ended up as a second wife to him, which in her opinion, was not a good thing to do, but she had been driven to it out of desperation. She said,

"If you don't own a house, you will be driven away like a dog, and because of life's hardships you will find yourself establishing relationship with married men, which is bad." (Interview at Mhaji, 9 November 2019)

Now that she owns these properties, she evaluates her past and current situation as follows,

"Some men are not liberated by education. They severely oppress their wives, and the wives cannot do anything. If you fight for your rights, they create situations that will eventually harm you so that you don't benefit from compensation and properties." (Interview at Mhaji, 9 November 2019)

Recently, it has been widely advocated that women should own assets, such as land, and should exercise control over them. Since the ownership of assets such as land and a house provides a woman with security and tends to moderate men's violent practices [29], married women misrecognize the domination associated with it. However, having a plot to farm does not guarantee freedom to make use of the products of that land, nor control over expenditure of the income generated from the harvests 
as long as the harvests are taken to a house built by a man or built on his land. Some men use asset ownership by a woman as a control mechanism. Men pretend to surrender control of some plots of land by transferring ownership to their wives, who eventually feel loved and secure by having control of production. As a result, women put a great deal of effort into tilling, planting, weeding, and the like to improve yields and, thus, increase harvests. However, normally such ownership and control fades at the beginning of the harvest season, when men resume their dominance and exercise control over the farm's production. In one case, a woman from Mhaji village who is married as a second wife was made aware of misrecognition of her rights when she was given 1.5 acres of land as hers to produce for the benefit of her household. She put more effort into her farm, hoping to earn a substantial income at harvest, but this did not materialize, as her husband controlled the produce and the income generated from the harvests. Narrating her experience, she said:

"This house is like a government asset. When you are given a farm, you will go and cultivate it, but the harvests belong to the government. You cannot plan for utilization of the harvests because though he told you the farm is under your control, he takes the harvests. When you sell some products, he takes the money. If you ask why this is, he asks you back if that is your property. He says it is in his house." (Interview 9 November 2019).

The amount of coercive power exerted by the husband establishes consent to and complicity with power relations by both the dominator and the subordinate, which ultimately legitimizes and internalizes symbolic violence. Inequality and violent practices are spread across the villages that experience rampant tree planting activities. Such irregularities are manifested as the misrecognition of women's potential, rights, and responsibilities, their consent to socially defined and accepted power relations between men and women, and their complicity with normalized symbolic power.

Consent and complicity on the part of women regarding practices that amount to symbolic violence have perpetuated decision-making practices that are skewed in the interests of men. Men's desire for financial resources has fuelled transactions of land and landed resources, leaving most families with sparse productive lands. Women are threatened and/or maltreated when they voice concerns over resource control. This long-standing patriarchal and misogynist system has established a skewed relationship between men and women. Apart from being deprived of the rights to resource ownership and control, women are regarded as homemakers, men as breadwinners [10]. With symbolic power, the man decides what to do with the land, and since women are not involved in decision-making, they are equally uninformed of the decisions that have been made, including which plots of land have been sold to domestic investors, leading to a loss of family lands. In this regard, one 53-year-old woman reported one particular bad experience with male domination. In her case, her husband sold one of her favourite parcels of cropland without her consent or awareness. When asked how it happened, she said:

"It was the rainy season, so I went to prepare the farm for growing maize. Arriving at the farm, I was astonished that our farm was invaded by tree growers, which made me come home quickly to ask him. He then told me that he sold it too." (Interview at Isaula, April 2018).

When asked what her reaction was, she simply said,

"I felt very bad but could not do anything. When a man decides, it is over. You cannot disagree."

Silence is one of the options women take to show their complicity with a potentially coercive situation. Disapproving a man's actions, which would be more appropriate, implies misbehaving. Misrecognizing their potential, women comply with the domination that is exerted over them to avoid more violence from their oppressive partners [11]. This is a practice whereby symbolic violence is recognized but not challenged, thus legitimizing its proliferation and influence over the subordinate [27]. If left unchallenged, a dominant person will continue the same practices as if they are legitimate. 
Tree planting has led to the conversion of much cropland into woodlots. Such conversions are done by families either to diversify their incomes for their households by undertaking tree businesses, or to sell cropland to domestic investors for tree-planting. When asked about tree-planting in her household, one woman from Ludihani village confirmed that they have several woodlots established by her family. However, since her husband does not participate in crop-farming, he has expanded tree-planting to family croplands. This is worrying her, as she sees their croplands dwindling, which will have adverse effects in the near future. Talking of her husband's practices, she said:

“He has planted trees on some of my maize farms. He does not know the risks we are going to face when we run out of food. He does not stay at home [but] rather spends most of his extra time at the pub for bamboo juice." (Interview 17 April 2018)

The dwindling of croplands is evidence of the land hunger that families will be facing in the near future. Women are worried about the impending hunger and poverty that might hit them when land and food are eventually gone. Men's planning, apart from being discriminatory, exacerbates poverty and hunger, thus undermining the global efforts stipulated in SDGs 1 and 2 to achieve zero poverty and zero by 2030 [2].

Drawing on Bourdieu's scholarly work Distinction of 2002, Angela Durey argues that the characteristics and practices of dominant groups can be changed or moderated through the critical practices of conscious subordinate groups, especially when such subordinates actively engage in activities that can influence change [35]. Similarly, Ojha stressed the status of misrecognition as dynamic, allowing it to be recognized, challenged and changed. It is thus for subordinate groups that are agents of change to recognize their potential and opportunities to instigate the desired changes in their interests [28].

\section{Concluding Remarks}

In this paper, we set out to uncover gender inequality with respect to women's access to family lands, in the context of the tree-planting surge in selected villages in the Southern Highlands of Tanzania. Drawing on Bourdieu's concept of symbolic violence, we observe the subjugation of women's voice and agency in claiming resources, hence, their limited involvement in land transactions. This is despite reforms to the system of land administration that have been introduced in Tanzania [23,41], especially in the study area, where land ownership, control, and utilization are still dominated by the patriarchal system, which discriminates against women. Women become victims of symbolic violence through traditional practices of inheritance, which limit their ability to have control over land. This happens because of their misrecognition of the violence inflicted on them. However, even in cases where symbolic violence is recognized, the affected women decide not to challenge it for fear of causing matrimonial disturbances. Moreover, although Colaguori [33] denies that violence is a destructive practice per se when he says, "Violence is therefore not only an active mechanism of social life, it establishes the political ontology of social life", he still acknowledges, as we do, that violence greatly affects women in terms of their access to both land and its associated benefits.

Effective implementation of the existing land laws and regulation is unavoidable. However, success will depend on overcoming the symbolic violence that disadvantages women. This calls for local governments at the village and district levels, NGOs such as PELUM, legislatures and policy-makers to promote gender equality in land management practices, as well as empowering women against dominant and discriminatory traditions and customs. This entails, among other things, capacity-building, regarding knowledge of the law among village land administrators-that is, the Village Council—and best practice of the same among villagers. Legal frameworks, laws, and regulations can affirm their right not only to family lands, but also to participation in decision-making process regarding family resources. 
Finally, although the conflict between men and women over resource ownership and control is nothing new, it provides room for debate and negotiation for a better balance of power. In a study of epistemic violence on Othering, Bunch [36] recommended that communities actively develop non-oppressive practices in respect of gender and social positions among others, as a way of stopping violence. Moreover, contrary to radical feminist perspectives that focus on women alone in dealing with society's gender challenges, we prefer to promote dialectical communication between women and men. This will both reveal and heal practices of symbolic violence and enhance gender equality in the management of land and other resources in the selected villages in the Southern Highlands of Tanzania.

Author Contributions: J.L. was involved in conceptualizing the study, writing the draft introduction, methodology and data collection, analysis, writing of findings and discussion. D.M. is involved as a supervisor, secured funding for the project, data curation, proofreading, discussion of the findings and conclusion. All authors have read and agreed to the published version of the manuscript.

Funding: This research was part of the Timber rush project that is funded by DANIDA with grant number 15-P02-TAN.

Conflicts of Interest: The authors declare no conflict of interest.

\section{References}

1. Fonjong, L.N. Gender Roles and practices in natural resource management in the North West Province of Cameroon. Local Environ. 2008, 13, 461-475. [CrossRef]

2. UNDP. Sustainable Development Goals (SDGs): Empowered Lives, Resilient Nations; UNDP: New York, NY, USA, 2015.

3. Wineman, A.; Liverpool-Tasie, L.S. Land markets and the distribution of land in northwestern Tanzania. Land Use Policy 2017, 69, 550-563. [CrossRef]

4. Follo, G.; Lidestav, G.; Ludvig, A.; Vilkriste, L.; Hujala, T.; Karppinen, H.; Didolot, F.; Mizaraite, D. Gender in European forest ownership and management: Reflections on women as "New forest owners". Scand. J. For. Res. 2016, 32, 174-184. [CrossRef]

5. Idris, I. Mapping Women's Economic Inclusion in Tanzania. KD4 Helpdesk Report 332; 2018. Available online: https://assets.publishing.service.gov.uk/media/5b432d9e40f0b678bc5d01c1/Barriers_to_ womens_economic_inclusion_in_Tanzania.pdf (accessed on 2 December 2019).

6. Pedersen, R.H. A Less Gendered Access to Land? The Impact of Tanzania's New Wave of Land Reform. Dev. Policy Rev. 2015, 33, 415-432. [CrossRef]

7. Homberg, H.v.d. Gender, Environment and Development: A Guide to the Literature; University of Amsterdam: Amsterdam, The Netherlands, 1993.

8. Gurung, B.; Thapa, M.T.; Gurung, C. Briefs/Guidelines on Gender and Natural Resources Management; Organisation Development Centre ODC: Kathmandu, Nepal, 2000; Volume 6.

9. Van Aelst, K.; Holvoet, N. Intersections of Gender and Marital Status in Accessing Climate Change Adaptation: Evidence from Rural Tanzania. World Dev. 2016, 79, 40-50. [CrossRef]

10. Alliyu, N. Patriarchy, Women's Triple Roles and Development in Southwest Nigeria. Int. J. Arts Humanit. (IJAH) Bahir Dar-Ethiop. 2016, 5, 94-110. [CrossRef]

11. Thapar-Björkert, S.; Samelius, L.; Sanghera, G.S. exploring symbolic violence in the everyday: Misrecognition, condescension, consent and complicity. Fem. Rev. 2016, 112, 144-162. [CrossRef]

12. Kirk, G. Women Resist Ecological Destruction. In A Diplomacy of the Oppressed: New Directions in International Feminism; Zed Books; Ashworth, G., Ed.; Lehtinen: London, UK, 1995.

13. Alemu, G.T. Women's Land Use Right Policy and Household Food Security in Ethiopia: Review. Int. J. Afr. Asian Stud. 2015, 12, 56-66.

14. Fox, L.; Wiggins, S.; Ludi, E.; Mdee, A. The Lives of Rural Women and Girls What Does an Inclusive Agricultural Transformation That Empowers Women Look Like? Overseas Development Institute: London, UK, 2018.

15. Ngaga, Y.M. A Platform for Stakeholders in African Forestry. For. Plant. Woodlots Tanzan. 2011, 1, 80. 
16. Lusasi, J.; Friis-Hansen, E.; Pedersen, R.H. A typology of domestic private land-based investors in Africa: Evidence from Tanzania's timber rush. Geoforum 2020. [CrossRef]

17. Olwig, M.; Noe, C.; Kangalawe, R.; Luoga, E. Inverting the moral economy: The case of land acquisitions for forest plantations in Tanzania. Third World Q. 2015, 36, 2316-2336. [CrossRef]

18. PFP. Forest Plantation Mapping of the Southern Highlands. Iringa, Tanzania. 2017. Available online: http://www.privateforestry.or.tz/uploads/Forest_Plantation_Mapping_SH_Final_Report_3.pdf (accessed on 27 October 2019).

19. Moyo, S.; Yeros, P. Rethinking the Theory of Primitive Accumulation: Imperialism and the New Scramble for Land and Natural Resources. Social Science. In Proceedings of the IIPPE Conference, Istanbul, Turkey, 20-22 May 2011.

20. Locher, M. 'How come others are selling our land?' Customary land rights and the complex process of land acquisition in Tanzania. J. East. Afr. Stud. 2016, 10, 393-412. [CrossRef]

21. Bourdieu, P.; Wacquant, L. An Invitation to Reflexive Sociology; Polity Press: Oxford, UK, 1992.

22. Aveling, E.-L.; Cornish, F.; Oldmeadow, J. Diversity in sex workers' strategies for the protection of social identity: Content, context and contradiction. In Symbolic Transformation: The Mind in Movement through Culture and Society; 2013; pp. 302-322. Available online: http://eprints.lse.ac.uk/47797/ (accessed on 17 May 2019).

23. URT. The Village Land Act; URT: Dar es Salaam, Tanzania, 1999.

24. Wily, L.A. Community-Based Land Tenure Management: Questions and Answers about Tanzania's New Village Land Act, 1999; IIED: London, UK, 2003; Volume 120.

25. Calás, M.B.; Smircich, L.; Bourne, K.A.; Bilimoria, D.; Piderit, S. Knowing Lisa? Feminist Analyses of 'Gender and Entrepreneurship'. In Handbook on Women in Business and Management; Edward Elgar Publishing: Cheltenham, UK, 2013; pp. 78-105.

26. Eckert, P.; McConnell-Ginet, S. Chapter 1: An Introduction to Gender; Eckert, P., McConnell-Ginet, S., Eds.; Cambridge University Press: Cambridge, UK; New York, NY, USA, 2001.

27. Bourdieu, P.; Nice, R. Masculine Domination. Contemp. Sociol. A J. Rev. 2002, 31, 407. [CrossRef]

28. Ojha, H.R.; Cameron, J.; Kumar, C. Deliberation or symbolic violence? The governance of community forestry in Nepal. For. Policy Econ. 2009, 11, 365-374. [CrossRef]

29. Panda, P.; Agarwal, B. Marital violence, human development and women's property status in India. World Dev. 2005, 33, 823-850. [CrossRef]

30. James, D. How Bourdieu bites back: Recognising misrecognition in education and educational research. Camb. J. Educ. 2015, 45, 97-112. [CrossRef]

31. Fraser, N. From Redistribution to Recognition? Dilemmas of Justice in a 'Post-Socialist' Age. New Left Rev. 1995, 212, 68-94.

32. Snyder, K.A.; Sulle, E.; Massay, D.A.; Petro, A.; Qamara, P.; Brockington, D. "Modern" farming and the transformation of livelihoods in rural Tanzania. Agric. Hum. Values 2019, 37, 33-46. [CrossRef]

33. Colaguori, C. Symbolic Violence and the Violation of Human Rights: Continuing the Sociological Critique of Domination. Int. J. Criminol. Sociol. Theory 2010, 3, 388-400.

34. Okali, Christine. Gender Analysis: Engaging with Rural Development and Agricultural Policy Processes. In Future Agricultures (No. 026); Okali, Christine: 2012; Available online: www.future-agriculture.org (accessed on 19 April 2018).

35. Durey, A. Rural medical marriages: Understanding symbolic violence in the social practice of gender. Women's Stud. Int. Forum 2008, 31, 73-86. [CrossRef]

36. Bunch, A.J. Epistemic Violence in the Process of Othering: Real-World Applications and Moving Forward. Sch. Undergrad. Res. J. Clark 2015, 1. Available online: http://commons.clarku.edu/surj/vol1/iss1/2 (accessed on 4 June 2020).

37. Shannon, S.E. Three Approaches to Qualitative Content Analysis. Qual. Health Res. 2005, 15, 1277-1288. [CrossRef]

38. Meinzen-Dick, R.S.; Quisumbing, A.; Doss, C.; Theis, S. Women's land rights as a pathway to poverty reduction: Framework and review of available evidence. Agric. Syst. 2019, 172, 72-82. [CrossRef]

39. Mi, C.; Park, C.M.Y.; White, B. Gender and generation in Southeast Asian agro-commodity booms. J. Peasant. Stud. 2017, 44, 1105-1112. [CrossRef] 
40. UNDP; URT. Tanzania Human Development Report 2014; Economic Transformation for Human Development; UNDP: Dar es Salaam, Tanzania; URT: Dar es Salaam, Tanzania, 2014.

41. URT. The Village Land Regulations; URT: Dar es Salaam, Tanzania, 2001.

42. Sen, A.K. Development as Freedom; Oxford University Press: New York, NY, USA, 1999.

Publisher's Note: MDPI stays neutral with regard to jurisdictional claims in published maps and institutional affiliations.

(C) 2020 by the authors. Licensee MDPI, Basel, Switzerland. This article is an open access article distributed under the terms and conditions of the Creative Commons Attribution (CC BY) license (http://creativecommons.org/licenses/by/4.0/). 